UDC 32

Emil ORDUKHANYAN

\title{
A COMPARATIVE STUDY OF POLITICAL PROCESS: THEORETICAL AND METHODOLOGICAL ISSUES
}

\begin{abstract}
The article explores the theoretical and methodological foundations of political process based on the analysis of relevant works in this field of study. The institutional, behavioural, structural-functional approaches, as well as conflict, discourse, and other methods of political process analysis, are examined.

Summing up the results of explored issues and considering the political process as a dynamic and nonlinear political phenomenon that can vary in time, we concluded that its variations depend on the impact of various direct or indirect factors and circumstances mainly related to political discourse content and its type of manifestation.

A comparative analysis of political process through its theoretical and methodological approaches has truly shown that any particular approach can be efficient only in an appropriate society or political regime. In case of other situation and circumstances, the same approach cannot be applied efficiently to study and to analyze the political process. Only discourse approach can be considered as universally efficient because all political processes regardless political regime type or other factors have their own discourses which reflect the peculiarities of the political process due to the political culture model, dominant in the given society.
\end{abstract}

Keywords: political process, comparative analysis, theoretical approach, methodological approach, discourse, political culture.

The political process, as one of political science primary categories, is an important basis for political analysis. The political reality is created as a result of human activity, and it is connected with interrelated political interests' realisation aiming to achieve predefined goals. Within the framework of the political process, individuals, groups, organisations, institutions, various political entities or factors interact with other ones (Degtyarev, 1998, p. 147). These actions take place in a certain political time and space, resulting as an interconnected sequence of political influences. And such a sequence is perceived as a political process (Meleshkina, 2001, p. 5). These actions are mainly carried out by the mediation of political institutions which operate in the pursuit of their own political interests. In democratic regimes, the political process simply reflects people's sovereignty. It means that people's interests and demands directed to political elites cannot be overlooked in this process. Hence, among the prerequisites for political process formation, the issues of social origin are of the utmost importance. In this case, the political agenda is shaped taking into account social interests and the possibilities for their realisation. Of- 
ten, political developments may lead to political system change by their sequences (Shutov, 1994, p. 19), having a crucial impact on the dynamics of political system functioning.

\section{Theoretical Aspects of Political Process}

$$
\text { Analysis }
$$

In the professional literature, there are several basic approaches to study the political process nature and content.

First of all the institutional approach proponents consider the political phenomena by the transformation of political institutions as political process main subjects. In this case, the social infrastructure is taken into account partially or indirectly because it is considered of secondary importance. The chronological limits are small: at best, they include only certain historical events.

Secondly, the representatives of the behavioural approach consider individuals or groups of people as subjects of politics. That's why in this case the political process is perceived as a result of these subjects' behaviour, political will and interests. However, in this regard, the broader and structural aspects of the political process are not fully reflected. Thus, chronological measurement units are also small. They only allow exploring politics within the framework of daily life.

Thirdly, the structural-functional approach emphasises the importance of internal structural and functional elements of the political system in the context of the political process. In this case, not individuals and groups, but central institutions of the political system (and the whole system itself), as well as their functional-role structure are considered as units of analysis (Isayev, 2013, p. 93). The main focus is on the meso-level and macro-level of the political process, which is characterised as political system reactions' integrity to the environment, the purpose of which, as it notes D. Easton, is the making of an acceptable decision for leading groups of interests (Easton, 1965).

Political processes differ by their nature and typology. In this context Y. Meleshkina rightly points out that political processes differ by their volume, actions, factors, by the interaction between them, and by other characteristics. Thus, the types of the political process are distinguished by some criteria (Meleshkina, 2001, p. $6)$.

According to the multi-scale nature of the political process, they distinguish the daily political process which is carried out by direct interaction of individuals, groups, and partly by institutions. For example, the legislative process in parliament. Another type of political process is the historical political process, which includes larger factors, groups and institutions. These processes are related to some historical events, such as the political revolution. The foundation and development of any political party can also be considered as a historical process. And finally, the author distinguishes the evolution political process which is characterised by the participation of large groups, factors, institutions, being measured with extensive chronological inclusion. The transformation of polis to empire or the modernisation of the political system as a result of political reform can be considered as relevant examples for this type of political process. The democratic transition as a result of previous system demolition and competitive elections' realisation can also be a relevant example (Meleshkina, 2001, pp. 6-7).

It should be noted that all types of abovementioned processes have been also reflected in the Armenian political reality. Actually these 
processes are universal since each state does not make its modernisation way according to the linear development logic. It is also necessary to underline that besides the evolutionary political processes, large-scale revolutionary political processes can also lead to the systemic, regime, administrative, social and other changes. Even within the framework of modernisation theory, S. Huntington does not exclude the effectiveness of revolutionary political modernisation, if evolutionary developments are permanently ineffective (Huntington, 1968).

Referring to political process typology, A. Solovyev notes that for the society political processes can be distinguished to basic and peripheral types. The basic processes lay on the change of systemic properties of political life (for example, the formation of state institution by the government). As for peripheral processes, they lay on less relevant changes that in principle, cannot have any severe impact on the dominant facilities of authorities. The author also defines closed and open, sustainable and transitional types of the political process (Solovyev, 2000, p. 292).

A closed political process is a change that can be assessed as monovalent within the framework of better/worse, desirable/undesirable criteria. An open political process is a change that allows presuming what kind of positive or negative impact it has on the subject, and what kind of strategy must be chosen for the future. In other words, such processes characterise the changes that occur in the most incomprehensible political situations. Sustainable political processes presume a stable reproduction of political relations. Furthermore, transitional processes imply a lack of basic features of the power organisation, which occurs in the condition of main subjects' unbalanced political activity (Solovyev, 2000, p. 293).
From this perspective, it is necessary to refer to political process theory, which gives a more complete picture of behavioural and processual phenomena in politics.

The standard explanation for social movement mobilisation, known as political process theory (PPT), emphasises the role of political opportunities, mobilising structures, and framing processes, along with protest cycles and contentious repertoires. Developed in the US in the 1970s and 1980s and rooted in an analysis of civil rights struggles, PPT focuses on the interaction between movement attributes, such as organisational structure, and the broader economic and political context. Critics argue that the theory is overly structural and invariant. Recent research by core PPT theorists has shifted focus to a more dynamic analysis of the reoccurring mechanisms and processes of contentious politics. PPT is the culmination of a series of critiques against the then-prevailing social scientific view that protestors and other social movement participants were irrational mobs, overwhelmed by a collective mentality. Movements did not result from alienation or abnormal psychological dispositions but instead were meant to achieve political ends and resolve legitimate grievances. Three precursors to PPT are noteworthy for their contributions to establishing this new analysis (Caren, 2007, p. 1).

First, M. Olson's (1965) analysis of collection behaviour turned old notions about the irrationality of protestors on its head, exploring the rational and deliberate choices that individuals made before joining a movement. Second, in an influential analysis of the farm workers' movement, J. McCarthy and M. Zald found that the availability of resources to the movement, as opposed to the degree of oppression, explained much of the variation in the level of mobilisation. 
This resource mobilisation perspective counted more than just material goods as resources, including aspects such as organisational strength and the presence of elite allies (McCarthy \& Zald, 1977, pp. 1212-1241). Third, F. Piven and R. Cloward (1978) brought attention to important aspects of the economic and political system. Only during periods of great system-wide crisis, such as during the Depression, for example, were movements able to extract concessions from elites.

It should be noted that the consideration of this theory's separate points allows understanding the numerous political and civil movements in Armenia as a demonstration of political culture's participatory component, where irrational elements never dominate because the public demands were the reflection of objective reality.

The combination of the three approaches mentioned above forms the PPT basis. One of PPT's fundamental works is C. Tilly's "From Mobilisation to Revolution", where the author synthesises these three approaches with other political sociologists' views. C. Tilly (1978) insists that the interaction of three (interests, organisation, and opportunity) constituent elements explains the level of mobilisation and collective action. The interests represent the potential outcomes of participation. The organisation represents the common identity and networking level. And the opportunity represents the political power volume, the probability of pressure, and the vulnerability of target as well. His work has a large indirect impact on a social movement. Meanwhile, D. McAdam's (1982) subsequent analysis of the Civil Rights Movement became PPT's central text (p. 34).

PPT crystallised in D. McAdam's 'Political Process and the Development of Black Insurgency" work where, drawing on earlier critiques of classical approaches and building on resource mobilisation and especially the work of C. Tilly, D. McAdam, he analyses the rise and decline of the US Civil Rights Movement as a direct result of three factors: political opportunities, indigenous organisational strength, and cognitive liberation (Caren, 2007). Political opportunities resulted from "any event or broad social process that serves to undermine the calculations and assumptions on which the political establishment is structured" (McAdam, 1982, p. 41).

The definition was broad, and his examples included wars, industrialisation, international political realignments, prolonged unemployment, and widespread demographic changes. Political opportunities worked indirectly by changing the degree of power inequality between the challenging group and the target. Among the opportunities that D. McAdam found leading up to the Civil Rights Movement was the Southern black population shift from a rural to the urban environment, the decline in lynchings, and the potential for international embarrassment during this phase in the Cold War (Caren, 2007, p. 2).

A second factor that encouraged mobilisation was the strength of indigenous organisations. These are not the organisations that were formed in the heat of the struggle, but rather the preexisting political and potentially political organisations that existed among the aggrieved community. The third element of D. McAdam's political process model is a sense of cognitive liberation among potential social movement participants. This is a result of a group process and flows directly from the political opportunities and through local organisations. In order to participate, D. McAdam argues, drawing on F. Piven and R. Cloward, individuals must feel that the current political system lacks legitimacy and their social movement participation could make 
meaningful change happen (Caren, 2007, p. 2).

It should be noted that since McAdam's formulation, the PPT has evolved. The cognitive liberation and indigenous organisational strength have been replaced by mobilizing structures. As for political opportunities - the element which has received the most attention - has been both narrowed and broadened. Additionally, S. Tarrow's (1994) notion of protest cycles is sometimes included as a part of PPT, as is C. Tilly's concept of repertoires of contention (Caren, 2007).

Moving away from the explicit bias in favour of formal preexisting organisations in D. McAdam's indigenous organisational strength, PPTists moved towards an analysis of mobilising structures, which are "those collective vehicles, informal as well as formal, through which people mobilise and engage in collective action" (McAdam, McCarthy \& Zald, 1996). This includes not only preexisting groups but also movement organisations and the informal networks among potential activists (Caren, 2007, p. 3).

A fourth concept that is often associated with PPT is the protest cycle. This refers to historical periods of heightened contention across the political sphere, such as in 1968 in the US or 1989 in Eastern Europe, when a host of groups was challenging the legitimacy of the state. As a new political opportunity usually affects more than one group and as frames are often transferable across movements, movements that are not obviously linked can share similar life courses (Caren, 2007, p. 3). In this context, it is also important to consider the national movements emerged at the end of Soviet-era when people of Soviet republics began independent actions including those in Armenia where these actions turned into a national movement as a political process.

C. Tilly rightly points out that the limited set of ways that actors can make claims constitutes the repertoire of contention. He finds that the modern repertoire of contention, which includes strikes, demonstrations, and social movements, originated in the second half of the nineteenth century (Tilly, 1995, pp. 15-42). In this regard, it is necessary to partially agree with the author's claim that these types of complaints emerged in the second half of the $19^{\text {th }}$ century because in this case different protests emerged in earlier historical periods can be ignored. Consequently, in these two cases, the difference is that the complaints addressed to governments in earlier historical periods were vehemently denied by the use of offensive force, even leading to the physical elimination of complaining people. ${ }^{1}$

Thus, all these elements - political opportunities, mobilising structures, framing processes, protest cycles, and contentious repertoires, constitute the core of contemporary PPT research. In addition to explaining the dynamics of public movements' rise or decline, these elements are also used to explain the nature of social and political protests and their results.

It is important to note that in many other types of research of political processes, the political possibilities are viewed as key elements. Sometimes the terms of "political opportunities" and "political process theory" are used as equivalents. However, it should be noted that many, but not all researchers have touched upon the critical analysis of political opportunity element.

J. Goodwin and J. Jasper (2004) are the scholars who have critically approached the

1 See more in detail in the following work: Ordukhanyan, 2010. 
PPT issue by defining it as mostly structured, centring stable, external factors and analysing non-structural features as if they were structures. The authors see mobilising structures, including both formal and informal networks of individuals and institutions, not so much as causal factors for social movement emergence, but rather implicit in the notion of a movement as a collective. As such, it adds little to our understanding of the conditions for movement emergence. Framing process, in contrast, they see as a limited concept, forced to carry all of the non-structural elements, while ignoring such relevant factors as emotions, symbols, and moral principles (Caren, 2007, p. 3).

Finally, D. McAdam, S. Tarrow, and C. Tilly (2001), as central PPT specialists, in their later work have moved away from general causal arguments to a more dynamic approach to the study of "contentious politics." In place of opportunities, mobilizing structures, and framing processes, they emphasise environmental, relational, and cognitive mechanisms. The emphasis is not so much on asserting that all three are causally necessary, but on identifying the specific mechanisms within each that can be found across multiple movements.

In this regard, the political process in Armenia is a multi-layered and multi-vector phenomenon that can be characterised as the integrity of activities made by institutional and noninstitutional political actors interested in implementing their functions. It is important to note that political process prerequisites should be based on the logic of public demands so that they can be perceived as legitimate. The peculiarities of the political process stem from the essence of political subjects and the interactions existing between them.
Methodological Aspects of Political Process

$$
\text { Analysis }
$$

In methodological regard to the political process, various scientific sources offer different definitions, which may be similar or dissimilar by some of their characteristics. The study of professional literature shows that the definition of the political process is due to methodological tools that researchers mostly focus on when studying political phenomena as a component of the political process, such as political participation, political behaviour, political regimes, the system, etc.

The nature of politics as a process allows seeing the strict limits between the subjects' relationships from the point of view of state power. As the political process coincides with the entire political sphere, some researchers, such as J. Rose (1971) identifies it with the whole politics. Meanwhile, C. Merriam (1931) identifies the political process with behavioural integrity of power subjects. As a proponent of the institutional approach to political process research, S. Huntington (1968) links it with the functioning and transformation of power institutions. As for D. Easton (1953), he defines the political process as the integrity of political system responses to environmental challenges. R. Dahrendorf (1988) emphasises the dynamics of competition between conflicting groups for status acquisition and power resources. And he describes the political process as a complex set of events that determine the nature of the activities of state institutions and its impact on society. K. Mannheim (1950) describes the political process as a complex set of events that determine the nature of state institutions' activities and their impact on society. Russian researcher Yu. Averyanov 
(1993) defines the political process as a social process that differs from legal, economic, ideological and other processes, which has a precise completion as an exact process with certain scope.

It should be noted that, along with the above mentioned political process definitions, it is also necessary to propose a new approach for political process research. This will lead to a specific methodological core, which in this case is the discursive approach that also affects the political culture. Taking into account the peculiarities of the political process and coupled with other methods of political process research, this approach allows for a more systematic and complex study of this problem.

In general, there are three basic methodological approaches to political process research T. Parsons' "Structural-Functional Approach", R. Dahrendorf's "Conflict approach", and C. Merriam's “Behavioral approach".

T. Parsons (1975) examines the political process from the view of its functioning, both in terms of the society's political system as integrity and as separate constituents, considering the phenomenon of power as a priority. Nevertheless, Parsons considers the political process as a unique integrator that allows transforming the political system from one state to another. The most important for him is the power cycle in the political process, which is a self-sufficient power function. In this case, power is perceived as a mediator, which is circulating in the political system (Parsons, 1997, p. 479). The social systems were perceived by T. Parsons as systems being shaped between acting subjects through social interaction. While defining the social structure, T. Parsons distinguishes four independent variables, values, norms, collectives, and roles. Thus, as one of "structural-functional approach" au- thors, he closely interconnects the concepts of the political process, political system, and political power. In this case, it is important to address the Parsons' perception of society because the functional approach to the political process is based on its definition as a social system. "We define the society as a kind of social system that has the highest level of self-sufficiency in its environment and includes other social systems" (Parsons, 1966, p. 48).

As for R. Dahrendorf's conflict approach to political process research, the author suggests viewing the political process as an obvious or hidden struggle, conflict as well as consensus, cooperation for very certain material resources and social status. At the same time, the researcher notes that while all social conflicts structural motives' explanation is impossible, the process of conflict settlement with its certain structural states is most likely applicable to its all different forms. Social conflicts stem from the structure of societies which are tended to the constantly crystallizing clashes between organised parties (Dahrendorf, 1990, pp. 69-75). Then R. Dahrendorf (1993) states that conflict is the father of everything, that is, the driving force of changes, and the reasonable restriction of social conflicts is one of the major issues of politics (pp. 31-35). The author of conflict approach divides the political process to two sub-processes, confrontation and consolidation. That implies disclosure of political process essence from the perspective of policymakers' conflicting and unifying. All this is perceived by R. Dahrendorf (1972) as "organised different sides".

In "The New Aspects of Politics", summarizing the achievements in the field of political research as a positive phenomenon, C. Merriam emphasises that it is necessary to consider the social forces from the perspective of their links 
with political processes. The researcher identifies the difficulty of examining political issues like a lack of correct knowledge and measuring criteria for political processes' sequence. That's why C. Merriam suggests developing special technologies for modelling political issues. From this view, Merriam proposes to enrich his / her own social science knowledge by statistical, anthropological, psychological and other knowledge when studying political processes. As a result, C. Merriam (1997) suggests studying the political process in the context of "behaviourism", especially emphasizing that "the unstoppable aspiration to reveal biological and physical secrets of nature will create enormous opportunities for a deeper understanding of humans political behaviour that even the most sharp-sighted prophets cannot preview" (pp. 176, 177, 182, 183).

The comparative analysis of above-mentioned methodological approaches shows that each of them reflects a degree of development for a particular political science tradition by completing and not contradicting one another at the same time. Actually, T. Parsons, R. Dahrendorf and C. Merriam's approaches to political process research are comparable in the regard of political science methodologies. The theoretical and applied political science development shows that researchers exploring political process widely use its entire methodological arsenal. The approaches of the above-mentioned authors are considered as classical. Nevertheless, according to modern political science requirements, it is justified that they need to be supplemented. These approaches emphasise specific aspects of the political processes, such as political actors' behaviour, their structural features, and their relationships' conflict nature. These are the necessary components of the political process but they are not sufficient to create a comprehensive un- derstanding of the political process. Therefore, these methods need to be revalued by supplementing the methodological framework.

For example, L. Gumplowicz (1999) offered to observe the political process as a universal social development factor and intergroup struggle. Thus, he can be considered as a proponent of "conflict" tradition for political process analysis. As for E. Durkheim (1990), he claimed that applied sociology allows studying social behaviour and political process. Unlike him, G. Tarde (2000) suggested exploring social and political processes by psychological approach. Other researchers, such as G. Le Bon (1910) proposed to insert the elite activity into the basis of social evolution. Furthermore, in that case, he considered every revolution a mass hysteria as a kind of social-political process. V. Pareto (1961), when elaborating the theory of illogical activity, referred to the irrational and illogical nature of human behaviour that, in his opinion, has a considerable impact on social process development. In this regard, his theory is quite close to the behavioural concept of political process research. This list of researchers can continue, and we can point out other approaches too. But in this case, the important thing is that one integrity or a complex of these approaches should be found which will allow studying the political process thoroughly, taking into account the current political settings.

Among the methodological approaches of political process analysis, the discourse approach has an extremely important significance, the theoretical basis of which was laid down by the representatives of Cambridge and Oxford University philosophy schools in the 50s of 20th century. The first results of political process discourse analysis were published by P. Laslett and J. Fishkin (1979). Moreover, since the 1970s, the 
term "discourse" has been widely used in political process analysis. In the 1980 s, there were created centres for semiotics, which are engaged in political discourse analysis. They focus mainly on T. van Dijk's (2008) critical discourse analysis. The research centres' analysts begin to pay attention not only to the content of discourse but also to the technique of political discourse analysis. Since then, political discourse analysis becomes an independent methodological approach for political process research (Baranov \& Pikalov, 2003).

In the context of political process analysis, the specialists often use the "scope of discourse" studying. According to J. Pocock (1985) and Q. Skinner (1978) statements, the scopes of discourse are "system-creating". For this phenomenon, the terms "language" and "ideology" are often used. It is this sense when they talk about liberalism, conservatism, and other ideological discourses.

It is noteworthy that political discourses can have scenarios that allow to consider them as an entity. For example, meeting, election rally, and others that differ by their discourse scenario, meanings, and other criteria. This circumstance also gives an opportunity to forecast political process development.

The postmodernist approach is one of the most common approaches to political discourse analysis. This approach is gradually gaining in social sciences. Especially in political science, it is considered as one of the modern directions of political analysis. The core of this approach is that postmodernists exclude the existence of a universal reality that is acceptable for everyone and it will be possible to explore and explain accurately. The behaviour of people creates the world around us. The more ideas are spread, the more people start believing them and acting accordingly. These ideas, embedded in specific rules, norms, institutions and public control mechanisms, create the reality itself.

The representatives of discourse approach suppose that the meanings should be sought not in the outside world but in the language that is the mechanism of creating and disseminating individual perceptions. Hence, the study of language becomes the main problem of science. Postmodernists note that only text analysis is sufficient for discourse understanding (Baranov \& Pikalov, 2003).

The majority of postmodernists believes that each reader can interpret the text faithfully: the reliability of interpretation depends exclusively on its subjective perception. D. Easton (1997) rightly points out that this perspective destroys both objectivity and subjectivity. The text speaks itself, and the dialogue is not between people. It is between the author and the reader ( $p$. 35).

In this sense, it should be noted that, in our opinion, only the text analysis is not sufficient to form a comprehensive understanding of the political process. For that reason, the linguistic aspects of the political process should not be considered as separate but as part of the process because the discourse is only a linguistic expression of the political process, despite the fact the process can also have behavioural and other expressions. Consequently, the combination of different methodological approaches, such as discursive, behavioural and other ones, can lead to a more sustainable foundation for a complete understanding, analysis and forecasting of the political process. In other words, the discourse approach is necessary, but not sufficient for a thorough analysis of the political process. 


\section{Conclusion}

Summing up the results of explored issues and considering the political process as a dynamic and nonlinear political phenomenon that can vary in time, we concluded that its variations depend on the impact of various direct or indirect factors and circumstances mainly related to political discourse content and its type of manifestation.

As for the conceptual basis, both typologies and methodological approaches, the political process needs to be supplemented with new theoretical and methodological foundations.

A comparative analysis of political process theoretical and methodological approaches has genuinely shown that any particular approach can be efficient only in an appropriate society or political regime. In case of other situation and circumstances, the same approach cannot be applied efficiently to study and to analyse the political process. If the institutional approach can be effective in an institutionalised political system, then it cannot have the same effectiveness in other systems with not developed political institutions where other models of public-political organisation are dominating. Hence, no matter how much political processes are comparable and have similarities, these processes will also differ from each other by their peculiarities. Moreover, the study of any political process requires the adoption of a particular approach or a combination of some approaches.

Only discourse approach can be considered as universally efficient because all political processes regardless political regime type or other political factors have their discourses which reflect the peculiarities of the political process due to the political culture model, dominant in the given society.

\section{REFERENCES}

Averyanov, Y. (1993). Politologiya: Entsiklopedicheski slovar' (Political Science: Encyclopedic Vocabulary, in Russian). Moscow: Moscow Commercial University Publishing.

Baranov, N., \& Pikalov, G. (2003). Teoriya politiki: Politicheski proces (Theory of Politics: Political Process, in Russian). Saint Petersburg: BGTU publishing. Retrieved September 21, 2018, from http://politics.ellib.org.ua/pages164.html.

Caren, N. (2007). Political Process Theory. Blackwell Encyclopedia of Sociology. Retrieved May 1, 2018 from: http://www.blackwellreference.com/su bscriber/tocnode? $\mathrm{id}=\mathrm{g} 9781405124331$ chunk g978140512433122 ss1-41.

Dahrendorf, R. (1972). Konflikt und Freiheit. München: Thomas Haker GmbH \& Co. KG.

Dahrendorf, R. (1988). The Modern Social Conflict. Berkeley and Los Angeles: University of California Press.

Dahrendorf, R. (1990). Doroga k svobode: demokratizatsiya i ee problemi $v$ Vostochnoi Evrope (Road to Liberty: Democratisation and Its Problems in Western Europe, in Russian). Questions of Philosophy, 9, 69-75.

Dahrendorf, R. (1993). Ot social'nogo gosudarstva k civilizovannomu soobshestvu (From Social State to Civilised Community, in Russian). Polis journal, 5, 31-35.

Degtyarev, A. (1998). Osnovi politicheskoi teorii (Foundations of Political Theory, in Russian). Moscow: Visshaya Shkola. 
Durkheim, E. (1990). Les règles de la method sociologique. Paris: Puf.

Easton, D. (1953). The Political System. An Inquiry into the State of Political Science. New York: Knopf.

Easton, D. (1965). A Framework for Political Analysis. New Jersey: Prentice-Hall.

Easton, D. (1997). The Future of the Postbehavioural Phase in Political Science. In K. Monroe (Ed.), Contemporary Empirical Political Theory (pp. 13-46). Berkeley: University of California Press.

Goodwin, J. \& Jasper, J. (2004). Rethinking Social Movements: Structure, Meaning and Emotions. Lanham, MD: Rowman \& Littlefield.

Gumplowicz, L. (1999).The Outlines of Sociology. Kitchener: Batoche Books.

Huntington, S. (1968). Political Order in Changing Societies. New Haven and London: Yale University Press.

Isayev, B. (2013). Vvedeniye v politicheskuyu teoriyu: osnovniye teoreticheskie podkhodi $k$ issledovaniyu politicheskogo procesa (Introduction to Political Theory: Main Theoretical Approaches to Political Process Research, in Russian).Saint Petersburg: SPB.

Laslett, P., \& Fishkin, J. (1979). Philosophy, Politics, and Society. Yale: Yale University Press.

Le Bon, G. (1910). La Psychologie politique et la défense sociale. Paris: E. Flammarion.

Mannheim, K. (1950). Freedom, Power, and Democratic Planning. New York: Oxford University Press.

McAdam, D. (1982). Political Process and the Development of Black Insurgency, 1930-1970. Chicago: The University of
Chicago Press.

McAdam, D., \& Tarrow, S., \& Tilly, C. (2001). Dynamics of Contention. Cambridge: Cambridge University Press.

McAdam, D., McCarthy, J., \& Zald, M. (1996). Comparative Perspectives on Social Movements: Political Opportunities, Mobilizing Structures, and Cultural Framing. Cambridge: Cambridge University Press.

McCarthy, J., \& Zald, M. (1977). Resource Mobilisation and Social Movements: A Partial Theory. AmericanJournal of Sociology, 82, 1212-1241.

Meleshkina, Y. (2001). Politicheski proces: osnovnye aspekti i sposobi analiza (Political Process: Main Aspects and Methods of Analysis, in Russian). Moscow: Ves Mir.

Merriam, C. (1931). The Making of Citisens: A Comparative Study of Methods of Civic Training. Chicago: University of Chicago Press.

Merriam, C. (1997). Noviye aspekti politiki (New Aspects of Politics, in Russian). In G. Semigin (Ed.), Anthology of World Political Thought. Foreign Political Thought of 20th Century (pp. 176-183). Moscow: Misl'.

Olson, M. (1965). The Logic of Collective Action. Cambridge, MA: Harvard University Press.

Ordukhanyan, E. (2010). Ishxanut'yan \& y'nddimut'yan qaghaqakan xosuyt'i verluc'ut'yun (The Discourse Analysis of Power and Opposition, in Armenian). Yerevan: Limush.

Pareto, V. (1961). On Logical and Non-Logical Action. In T. Parsons (Ed.), Theories of Society; Foundations of Modern Socio- 
logical Theory (pp. 1061-1062). New York: The Free Press of Glencoe.

Parsons, T. (1975). The Present Status of 'Structural-Functional' Theory in Sociology. Social Systems and the Evolution of Action Theory. New York: The Free Press.

Parsons, T. (1966). Societies: Evolutionary and comparative perspectives. New Jersey: Englewood Cliffs.

Parsons, T. (1997). O ponyatii "politicheskoi vlasti" (On the Notion of "Political Power", in Russian). In G. Semigin (Ed.), Anthology of World Political Thought. Foreign Political Thought of 20th Century (pp. 479-486). Moscow: Misl'.

Piven, F., \& Cloward, R. (1978). Poor People's Movements: Why they Succeed, How they Fail. New York: Vintage Books.

Pocock, J. (1985). Virtue and History. Essays on Political Thought and History, Chiefly in the Eighteen Century. Cambridge: Cambridge University Press.

Rose, J. (1971). Introduction to Sociology. Michigan: Rand McNally.

Shutov, A. (1994). Politicheskii proces (Political Process, in Russian). Moscow: Mos- cow University Publishing.

Skinner, Q. (1978). The Foundations of Modern Political Thought. Cambridge: Cambridge University Press.

Solovyev, A. (2000). Politologiya. Politicheskaya teoriya. Politicheskie tekhnologii (Political Science. Political Theory. Political Technologies, in Russian). Moscow: Aspect Press.

Tarde, G. (2000). Les lois sociales. Esquisse d'une sociologie (1898). (H. C Warren, Trans). Kitchener: Batoche Books.

Tarrow, S. (1994). Power in Movement: Social Movements, Collective Action and Mass Politics in the Modern State. Cambridge: Cambridge University Press.

Tilly, C. (1978). From Mobilisation to Revolution. Boston: Addison-Wesley.

Tilly, C. (1995). Contentious Repertories in Great Britain, 1758-1834. In M. Traugott (Ed.), Repertoires and Cycles of Collective Action (pp. 15-42). Durham: Duke University Press.

van Dijk, T. (2008). Discourse and Context: A Sociocognitive Approach. Cambridge: Cambridge University Press. 